\title{
The Factors Which Affecting Millennials Purchase Decision in Buying the Trending Clothing on An Online Shop "Shopee"
}

\author{
Rina Nur Asriani Djafar T. ${ }^{1}$, Hafied Cangara ${ }^{2}$, Suprratomo $^{3}$ \\ Program Studi Ilmu Komunikasi Fakultas Ilmu Sosial dan Ilmu Politik, Universitas \\ Hanasuddin, Jalan Perintis Kemerdekaan KM. 10 Makassar 90245 \\ Telepon (0411) 585024 /Fax (0411) $585024^{1,2,3}$ \\ \{rinanurasriani@gmail.com ${ }^{1}$, cangara_hafied@yahoo.com², sppratomo@yahoo.co.id ${ }^{3}$ \}
}

\begin{abstract}
The interest in advertising will influence buying interest before making the decision. This study aimed to describe the factors affecting millennials' purchase decisions in Makassar city from buying the trending clothing on an online shop "shopee." This study's research type is a descriptive statistic with the sample amounts to 45 taken by purposive sampling. Methods of data collection used questionnaires and interviews. The results show that millennials are interested in the trendy clothing advertising products on an online shop "shopee" because of the benefit, needs, price, trust and belief, the products, and an online shop "shopee" itself.
\end{abstract}

Keywords: Advertising; New Media; E-Commerce; Buying Interest

\section{Introduction}

The presence of technology has created enormous changes in human life in various fields. Especially with the internet's existence, which has become people's daily consumption in the current era of globalization. The role of technology is what brings human civilization into the digital era. Various groups have made it easier to access information circulating in many ways and enjoy cyber media (internet) facilities from digital technology freely and under control. New media means it is a communication tool using the internet network or a form of communication in cyberspace. The advantages of this internet communication network are the speed of sending and obtaining information and being data provider sophisticated, Cangara 2018. With the internet, online-based trading or business processes have been developed. Where sellers and buyers do not meet face-to-face, but with the internet being a liaison and medium communication through the electronic media. One of the e-commerce companies that is growing until now is shopee. Shopee is an electronic trading platform that bridges sellers and buyers to facilitate buying and selling transactions.

Based on iPrice's report data, the number of monthly web visitors to e-commerce Shopee in 2020 was 93.4 million, first with the most visitors. Various ways in which the companies and organizations, through the mass media, give satisfaction and attract the audience's attention, whether it is in print, broadcasting, and online-based media. One of the ways 
companies and organizations communicate is through an advertisement. Advertising is a form of company communication to the public to convey information about its products. Ecommerce Shopee is competing using advertising strategies in various media, especially online media.

According to Nielsen's report, the most searched for product purchases online on ecommerce is the category of fashion or clothing products. Everyone undoubtedly needs a garment which is our primary need. Starting from the types of work clothes, clothes for everyday life, and many more. As many as $61 \%$ of consumers buy it online. Advertising on online media is very beneficial for conveying information widely to audiences who will later become consumers and potential consumers who will generate interest in buying. Purchase intention can measure someone's possibility to buy a product; if the purchase intention is higher, the higher one's willingness to buy a product.

\section{Literature Review}

\subsection{Advertising}

According to Moriarty et al. (2011: 6), "Advertising (advertising) is a complex form of communication that operates to pursue goals and uses strategies to influence consumer thoughts, feelings, and actions. So advertising is a form of communication with a specific purpose to influence the target audience's thoughts and actions.

Furthermore, Einstein (2017: 5) states that "Advertising is paid communication that is used to persuade someone to buy a product or service from an identified sponsor. Advertising is disseminated through the media and can be in print advertisements, radio, television advertisements, or digital advertisements, any of which can be static or video-based. In short, the job of advertising is to convey the right message to the right people at the right time and place".

\subsection{New Media}

According to Cangara (2017:150) states that "New media (internet) is the result of engineering by information technology experts who have succeeded in combining interpersonal communication and mass communication. It is called mass communication because it can reach audiences globally, and it is said to be interpersonal because the messages created are directed and consumed personally. "

Furthermore, McQuail (2011:148) defines "New media as a variety of communication technology devices that share the same characteristics which are only possible with digitization and its wide availability for personal use as a means of communication." So diverse is the new media or New media that it is not easy to define. The free use of the internet for social networking has given rise to several influences on human behavior in communicating and in human relations (Darmastuti, 2011), such as changing traditional societies into modern societies accustomed to conducting transactions and negotiations online.

Dwiyono revealed (2018:12) several examples of social media, namely Facebook, WhatsApp, Line, Youtube, Twitter, Instagram. 


\subsection{E-Commerce}

The definition of "E-Commerce" itself is very diverse, depending on the perspective or glasses used. Association for Electronic Commerce in Indrajit (2002: 9) defines that "ECommerce is a business mechanism electronically."

According to CoimmerceNet in Indrajit (2002: 9) states that "E-Commerce is the use of computer networks (connected computers) as a means of creating business relationships. The process of buying and selling services or products between two parties via the internet or exchanging and distributing information between two parties in one company using an intranet.

\subsection{Buying Interest}

According to Schiffman and Kanuk (2007: 228), "Purchasing interest is a model of one's attitude towards the object of goods which is very suitable in measuring attitudes towards specific product, service or brand groups. Interest is part of the profit value that will affect buying interest. Profit value consists of perceived quality and received quality, namely the dimension of perceived price".

Kotler and Gary (2001: 117) define that "Purchase interest is an impulse that arises from within a person to buy goods or services in order to meet their needs". According to Widiastuti (2017: 14), to measure someone's buying interest, an indicator of a potential consumer's buying interest is used as follows:

a. Attention, is the attention of potential consumers to the products offered by the manufacturer. The message conveyed must attract the target audience because the message seen will immediately attract consumers' attention.

b. Interest, that interest potential consumers of the products offered by the manufacturer. When this attention is successfully obtained, the message must generate interest where later curiosity will arise regarding the product. Therefore it must be stimulated so that consumers are willing to try.

c. Desire, namely the desire of potential customers to have the products offered by the manufacturer. A good message must determine what consumers want in marketing the products displayed in the message.

d. Action (Action) is the stage where potential customers make purchases of the products offered.

\section{Research Methodology}

This research uses a quantitative research approach which is usually called a positivistic paradigm. A quantitative approach to test the theory, building a fact, explaining the relationship between variables, providing a statistical picture, estimating and predicting the results. The type of research that the author uses in this research is descriptive statistical research. Descriptive research is used to determine the factors in decision-making related to purchasing trendy clothing shop online "shopee" among millennials in Makassar.

The sample in this study were Millennials in Makassar City, with the technique sampling used was purposive sampling, which means a sampling technique with specific considerations. The criteria that have been determined are as follows: 1. Millennials who are in the $20-40$ year age category, 2. Millennial Instagram users, and 3. Millennials who have bought fashion 
products trendy shop online "Shopee" and have seen fashion advertisements trendy shop online "Shopee."

The sample that can be taken to represent the population is obtained by determining the number of samples according to Hair et al. This study depends on the number of indicators multiplied by 5 to 10 . The number of indicators in this study is nine indicators so that the number of samples that can be drawn is five multiplied by nine indicators to 45 samples.

The data measurement scale used is the Likert scale, a measurement to measure people's attitudes, opinions, and perceptions about social phenomena. Respondents will be allowed to answer each statement by choosing one of the answers provided. Each answer has a different weighting score, namely: Strongly Agree (5), Agree (4), Simply Agree (3), Disagree (2), and Strongly Disagree (1). Furthermore, to interpret the questionnaire's scores into a description, the range of the lowest scores to the highest scores can be described in the table below.

Table 1. Respondent Rating Range

\begin{tabular}{ll}
\hline \multicolumn{1}{c}{ Range } & Buying Interest \\
\hline $1-1.79$ & Very disagree \\
$1.80-2.59$ & Disagree \\
$2.60-3.39$ & Simply Agree \\
$3.40-4.19$ & Agree \\
$4.20-5$ & Very Agree \\
\hline \multicolumn{2}{c}{ Source: Umar $(2011.201)$}
\end{tabular}

Source: Umar (2011:201)

\section{Result and Discussion}

Table 2. Respondents' Responses to Indicators of Interest (Interest)

\begin{tabular}{|c|c|c|c|c|c|c|c|c|c|c|c|}
\hline \multirow{3}{*}{ No } & \multicolumn{10}{|c|}{ Score } & \multirow{3}{*}{ Mean Score } \\
\hline & \multicolumn{2}{|c|}{$\begin{array}{l}\text { SS } \\
(5)\end{array}$} & \multicolumn{2}{|c|}{$\begin{array}{c}S \\
(4) \\
\end{array}$} & \multicolumn{2}{|c|}{$\begin{array}{l}\text { CS } \\
(3) \\
\end{array}$} & \multicolumn{2}{|c|}{$\begin{array}{l}\text { TS } \\
(2) \\
\end{array}$} & \multicolumn{2}{|c|}{$\begin{array}{c}\text { STS } \\
(1)\end{array}$} & \\
\hline & $\mathbf{F}$ & $\%$ & $\mathbf{F}$ & $\%$ & $\mathbf{F}$ & $\%$ & $\mathbf{F}$ & $\%$ & $\mathbf{F}$ & $\%$ & \\
\hline 1 & 10 & 22,2 & 26 & 57,8 & 9 & 20,0 & - & - & - & - & 4,02 \\
\hline 2 & 18 & 40,0 & 18 & 40,0 & 9 & 20,0 & - & - & - & - & 4,20 \\
\hline 3 & 20 & 44,4 & 13 & 28,9 & 11 & 24,4 & 1 & 2,2 & - & - & 4,16 \\
\hline 4 & 25 & 55,6 & 12 & 26,7 & 7 & 15,6 & 1 & 2,2 & - & - & 4,36 \\
\hline 5 & 10 & 22,2 & 22 & 48,9 & 12 & 26,7 & 1 & 2,2 & - & - & 3,91 \\
\hline 6 & 16 & 35,6 & 19 & 42,2 & 9 & 20,2 & 1 & 2,2 & - & - & 4,11 \\
\hline \multicolumn{11}{|c|}{ Average } & 4,13 \\
\hline
\end{tabular}

Questionnaire Statement:

a. Fashion advertisement for Trendy the shop online "shopee" able to generate interest in the product offered.

b. I am interested in buying fashion advertising products trendy shop online "shopee" because the benefits that I will get.

c. I am interested in buying fashion advertising products trendy shop online "shopee" because I need it.

d. I am interested in buying fashion advertising products for trendy shop online "shopee" because the price offered is. 
e. The product's price in the fashion advertisement of trendy the online shop "shopee" follows my expectations. I am interested in buying products from trendy fashion advertisements through the shop online "shopee."

Based on the results of processed questionnaire data with several statement items given to respondents, the factors that determine millennial decision making after seeing the online shop "shopee" advertisement appear on Instagram social media where millennials take several considerations before making a take decision. The indicator with the highest average perceived by respondents is the indicator of interest with an average of 4.13 , which is in the interval 3.40 - 4.19. Respondents perceive they agree with the statement that interest in an advertisement affects purchase intention before finally making a decision. This interest in the form of millennial interest in buying a trendy fashion advertising product for the online shop "shopee" because of their interest in the product itself. When we open Instagram social media without thinking about buying a fashion product, but trendy fashion ads then appear/pop-up on our Instagram, we are then interested or taste the product.

Next, millennials' interest is to buy a trendy fashion advertising product for the online shop "shopee" because of its benefits. The benefits of a product are certainly a consideration in making a purchase. What are the benefits of the product that consumers will have their satisfaction to get? Furthermore, millennials agreed to buy trendy fashion advertising products for the online shop "shopee" because they needed these items. The need for a product becomes an internal impetus for a person to buy the goods/services offered to meet their needs.

Furthermore, millennials are interested in buying trendy fashion products from the online shop "shopee" because the price offered is in line with expectations and the "shopee" online shop. In online shopping, especially at the "shopee" online shop, consumers certainly make price considerations for buying a product. Consumers can compare product prices in the online shop "shopee" and other online stores via the internet before finally deciding to buy. Millennials also agree that they have expectations related to the price of a clothing product. If only the fashion product's price does not match expectations, millennials may refuse to buy. Millennials also agree to make purchases because, through the "shopee" online shop, this is supported by the online shop "shopee," which continues to increase every year. In 2020, "shopee" is in the first place for monthly web visitors.

Table 3. Respondents' Responses to Action Indicators (Action)

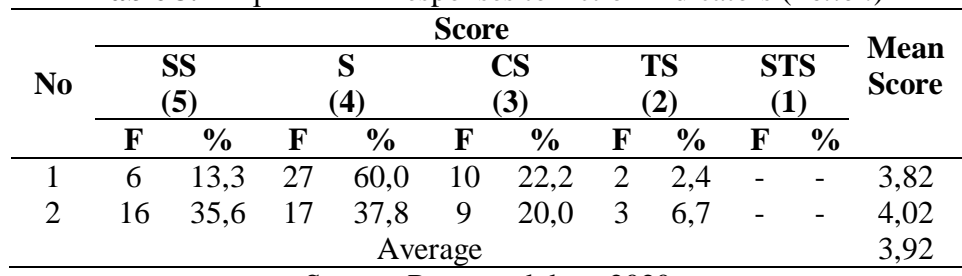

Source: Processed data, 2020

Questionnaire Statement:

a. Saya merasa percaya dan yakin untuk melakukan pembelian terhadap produk yang ditawarkan iklan busana trendy toko online "shopee"

b. Berbagai penawaran harga dan promosi yang ditawarkan iklan busana trendy toko online "shopee" membuat saya sesegera mungkin untuk melakukan pembelian

Furthermore, the action indicator we can see from the distribution of the statement questionnaire among millennials in the city of Makassar in point statements 1 and 2 . The 
respondents perceive that the actions to make purchases of advertising products fashion trendy online store "shopee" for their taste, trust, and belief. A total of $6(13.3 \%)$ respondents stated strongly agree, $27(60.0 \%)$ respondents agreed, and as many as $10(22.2 \%)$ respondents stated quite agree. The average value obtained is 3.82 , which is included in the agreed category, which means that millennials believe and are confident to purchase products offered by fashion advertisements for trendy shop online "shopee." Feeling confident and confident in a product will undoubtedly influence purchasing behavior. Trust and confidence can arise from expectations from within, from reviews from people regarding the advertised products, and models that offer products in these advertisements. A person's belief in a product influences their buying decision. Next, millennials in the city of Makassar agree that the various price offers and promotions offered by fashion advertisements for trendy the shop online "shopee" make them buy as soon as possible. As many as $16(35.6 \%)$ respondents stated that they strongly agreed, $17(37.8 \%)$ respondents stated that they agreed, and as many as $9(20.0 \%)$ respondents stated that they quite agreed. The average value obtained is 4.02 , which is in the agreed category, which means that millennials agree to make purchases as soon as possible because of the various price offers and promotions offered by fashion advertisements for trendy the shop online "shopee."

Making consumer decisions in buying a product is essential for a company. A successful company will undoubtedly be a company that can compete and survives in the current business competition era. This success is vital for a marketer. Suppose the company can develop a good marketing communication strategy pattern. In that case, it will arrive at the stage of buying someone or the consumption stage, then the post-consumption stage, where someone will re-purchase a product. This is in line with the results of interviews with millennials in the city of Makassar who stated that the reason for buying trendy clothing online shop "shopee" is because of a need, besides that they are interested in the product, a sense of trust in the shop for the reviews of other buyers. Respondents also stated that purchasing through online stores can save on gasoline costs by looking at a smartphone with the appropriate clothing size and fashion model. Millennials say they do not need to walk to an offline store, just use a smartphone to shop, and do not need to spend time, money, and effort.

Regarding the theory of uses and gratification, millennials solve the problem using social media, namely buying a clothes product and not having to walk far and save gasoline. Besides, respondents stated that the online shop "shopee" has many promotions, starting from discounts on products, cashback, and postage discounts. Moreover, because of the pandemic among millennials in Makassar, shopping online is an alternative option. We have to keep our distance from other people only to see their products via smartphone as a precautionary measure. The use of smartphones to shop online is by the theory of new media, which is defined as a technology-mediated communication product. Where in it, there is a convergence of media. One of the new media characters is flexible, where millennials in the city of Makassar can buy a product that is not well-known at any time.

\section{Conclusion}

This study shows that in making purchasing decisions after seeing trendy fashion advertisements for online shop through social media Instagram, millennials in Makassar city agree to distribute questionnaires. Respondents perceive that interest in an advertisement affects their buying interest before finally making a decision. The factors that determine millennials' decision-making in the city of Makassar in purchasing trendy clothes can be 
researched for the online shop "shopee" to continue developing and presenting exciting things to continue to be the online shop of choice and public trust.

\section{References}

[1] Cangara, Hafied. Pengantar Ilmu Komunikasi. Edisi Ketiga. Cetakan ke-18. Depok: PT Raja Grafindo. (2018)

[2] ---orencanaan \& Strategi Komunikasi. Edisi Revisi. Cetakan ke-3. Jakarta: PT Raja Grafindo Persada. (2017)

[3] Dwiyono, Prysmadana. Representasi Maskulinitas dalam Media Sosial (Analisis Semiotika pada Akun Instagram @dailymanly). (diakses dari, http://eprints.umm.ac.id/43080/). (2018)

[4] Einstein, Mara. Advertising: What Everyone Needs to Know. New York: Oxford University. (2017)

[5] Indrajit, Richardus Eko. Electronic Commerce, Strategi dan Konsep Bisnis di Dunia Maya. Jakarta: PT. Elex Media Komputindo. (2002)

[6] Iprice. Peta E-Commerce Indonesia. Diperoleh dari https://iprice.co.id/insights/mapofecommerce/. (2020)

[7] Kompasiana. Teknologi di Era Digital. Diperoleh dari https://www.kompasiana.com/rizkisaputranasution9466/5f3224c48c48256dfc3559b6/te knologi-di-era-digital?page=all. $(2020)$

[8] Kotler, Philip dan Gary Amstrong. Dasar-dasar Pemasaran. Jakarta: Prenhalindo. (2001)

[9] McQuail, Denis. Teori Komunikasi Massa. Edisi 6. Jakarta: Salemba Humanika. (2011)

[10] Moriarty, Nancy Mitchell dan William Wells. Advertising. Edisi ke 8. Alih Bahasa: Triwibowo B.S. Jakarta: Kencana. (2011)

[11] Schiffman dan Lesley Kanuk. Consumer Behavior. NewJersey: Perason Prestice Hall. (2007)

[12] Sirclo. 6 Kategori Produk yang Laris Dijual di Marketplace. Diperoleh dari, https://www.sirclo.com/6-kategori-produk-yang-laris-dijual-di-marketplace-apa-saja/. (2020)

[13] Sugiyono. Metode Penelitian Bisnis. Cetakan ketujuh belas. Bandung: CV. Alfabeta (2013)

[14] Umar, Husein. Metode Penelitian Untuk Skripsi dan Tesis Bisnis. Jakarta: Raja Grafindo Persada. (2011)

[15] Unpas. Internet yang Membangun Dunia E-Commerce. Diperoleh dari, http://www.unpas.ac.id/internet-yang-membangun-dunia-e-commerce-2/. (2012)

[16] Widiastuti, okta. Hubungan antara persepsi terhadap kualitas produk dengan minat beli bedak muka sariayu pada mahasiswi di universitas mercu buana yogya. (Online). (diakses dari, http://eprints.mercubuana-yogya.ac.id/245/. (2017)

[17] Widodo. Metodologi Penelitian. Jakarta: PT RajaGrafindo Persada. (2017) 